\title{
Signs and Stage Props in Tennessee Williams' Camino Real
}

\author{
Parvin Ghasemi \\ Department of Foreign Languages and Linguistics, Faculty of Humanities and \\ Literature, Shiraz University, Eram Campus, Eram St. 7194684795, Shiraz, Iran \\ e-mail: pghasemi54@gmail.com
}

\author{
Roshanak Yazdanpoor \\ Department of English, Razi University, Iran \\ e-mail: jesuistwi@yahoo.com \\ Aref Faghih Nassiri \\ Department of English, Mazandran University, Iran \\ e-mail: aref_453@yahoo.com
}

\begin{abstract}
Humans from the early times have used signs to facilitate the communication in the early societies. Semiotics is an approach wherein howness is dominant; it is the investigation of how meaning is created and communicated through systems of signs. In the dramatic texts meanings are conveyed by two different forms of language, stage direction and dialogue. Stage direction and dialogue are complementary and interdependent signifying systems. Stage directions are integral to the structure of dramatic texts and have important functions in their semantic construction. Tennessee Williams is one of the dramatists who use notes or stage directions in his plays. Through such stage devices as lighting, music and sound effects, colors, objects as symbols, transparent walls, the fluctuation of time, etc., he is after the representation of an abstract or spiritual meaning through concrete or material form. This study aims at analysis and examination of Williams' Camino Real's stage props and devices as signs and their relationships in the play with regard to semiotics as the theoretical framework and approach.
\end{abstract}

Key words: signs, semiotics, drama, stage props, stage directions, contradiction

The concept of sign is not new since humans from the early times have used signs to facilitate the communication in the early societies. In this manner, sign originally was a mean through which communication 
was facilitated. In spite of this incontrovertible fact about human's intrinsic tendency toward signs and their application in their life, early twentieth century is considered as the first time when the science of signs, semiotics, was officially and actually posed. Keir Elam (2002) defines semiotics, "Semiotics can best be defined as a science dedicated to the study of the production of meaning in society. As such, it is equally concerned with processes of signification and with those of communication, i.e. the means whereby meanings are both generated and exchanged" (p. 1).

Semiotics as a theory extends its domain to many scientific fields. Newton (1990) in Twentieth-Century Literary Theory, in his definition of semiotics attempts to show how its realm is extended to various aspects of human life and activity

Not only are languages and communication systems such as Morse code constituted by signs but, radical semioticians would argue, the world itself as it relates to the human mind consists entirely of signs since there can be no unmediated relationship with reality (p. 171).

He continues that although language is the basic and rudimental system of signs in human society, there are other signs which go beyond language; for example, "gestures, forms of dress" and even "eating" all are signs whose meanings are the result of the relation between signs (p. 171).

From this time on sign penetrated into different realms of human affairs from eating to the ways of dressing. Literature was no exception. Soon afterward, semiotics found its way in literary studies, narrative and poetry but drama, in spite of its high potential in using both verbal and nonverbal elements was not that much fortunate. Later on literary critics started to apply semiotics in theatre and drama as a new window toward its verbal and visual elements. . Tennessee Williams is one of the dramatists who use notes or stage directions in his plays. Through such stage devices as lighting, music and sound effects, colors, objects as symbols, transparent walls, the fluctuation of time, etc., he is after the representation of an abstract or spiritual meaning through concrete or material form. This study aims at analysis and examination of Williams' Camino Real's stage props and devices as signs and their relationships in the play with regard to semiotics as the theoretical framework and approach.

Thomas Lanier Williams, known as Tennessee Williams, was born on March 26, 1911, in Columbus, Mississippi. Tennessee Williams' 
influence, as Jackson (1975) puts it, "in the second period of theatre's growth" (p. 81), has brought about a new period in American theatre. After W.W.II and its devastating effect of tremendous bloodshed and death, the concept of reality changed in people's minds. Its harshness changed their view toward everything in life even art. Durham (1971) states that American drama was assiduously after finding new ways to depict this "particular range of sensibility", in this manner "verse" has not been the most appropriate medium. Seemingly, the best way of its portrayal has been "a new poetic drama which eschews verse for an eclectic but organic union of both verbal and nonverbal elements of theatre, which many critics have recognized and which Tennessee Williams, one of its major practitioners, calls 'plastic theatre' " (p. 3).

Tennessee Williams wrote one of his most imaginative plays, Camino Real in 1953. Camino Real is a kind of fantasy set in a parallel world. The setting of the play is the main plaza of a town in a Spanish-speaking world. The town is surrounded by desert and transportation to the outside world is sporadic.

Williams (1958) says, "More than any other work that I have done, this play has seemed to me like deconstruction of another world, a separate existence" (p. 119). The setting is a sort of surrealistic purgatory where the soul of its settlers is captured by despair and death. The succession of scenes in the play is counted as series of dreamlike blocks. The town's inhabitants all want to leave but their hopes are frustrated because of their own inadequacies, and Williams depicts it by the vast unknown desert stretched beyond the exit at the top of the town square.

According to Fleche (2010), Williams wrote in a period when "U.S. drama was becoming disillusioned with realism," so he used "allegory" as a mean to "achieve a critical distance from realistic technique" (para. 5). Maybe that is why Williams is unanimously acclaimed by critics, as the first dramatist who tried to use stage props and devices to unravel the inner side of the characters. In his plays, he is after an extra-verbal language to dig the deeper meanings out of the mind and life of the characters.

Semiotic theorists take signs or sign systems as their object of study. Drama is one of the cultural products in human societies whose communication occurs not only through verbal elements but also through non-verbal ones. So studying the semiotics of theatre is a way to understand the language of theatre, how stage messages are produced and conveyed to the audience to create the necessary communication. 
As mentioned before, despite the richness of drama in communicating with audience through the various options, devices, signs and symbols, it has received the least attention from semiotics whose main purpose is to analyze the signs and their relationship through communicating meaning. The aim of this study is to discuss semiotically Williams' influential work Camino Real in which such theatrical devices as light, music and stage props have been used as a way of penetrating into the deeper layers of the characters' thoughts, feelings and words. Such scrutiny of his play is impossible unless semiotics, as the appropriate means to decipher these layers of meanings, come into focus. Therefore, this study will analyze the aforementioned play of Williams in the light of semiotics; it will be the study of its signs, devices, stage props and their relationship to each other and to the themes and meanings they convey.

\section{SEMIOTICS AND SIGNS}

Signs are the windows to the world of reality and where we live and this window makes reality perceivable for us; it is what Chandler (1994) says about them, "We learn from semiotics that we live in a world of signs and we have no way of understanding anything except through signs and the codes into which they are organized" (Introduction section, para. 20); therefore, "the study of signs is the study of the construction and the maintenance of reality" (para. 20).

Peirce, as a semiotics theorist, has divided signs into three categories of icon, index and symbol. Describing these three types, Scholes (1982) says, "Any given sign is iconic to the extent that it signifies by virtue of some resemblance or similitude between the sign and what it stands for. Pictures and diagrams are the most common iconic signs" (p. 144). In indexical sign similarity is omitted and "a sign is indexical to the extent that there is a phenomenal or existential connection between the sign and what it signifies" (p. 144). Talking about indexical signs Scholes mentions foot print, smoke, natural signs as index. Symbolic sign is the third category in this division and also the one which needs meticulous attention in interpretation and definition since it is a "[t]ype of sign which signifies by virtue of an arbitrary, conventional habit of usage" (p. 148).

Signs do not have fixed domain and they merge into each other and as Peirce himself believes a sign should be interpreted based on the context wherein it has been used. Chandler (1994) points to this flexibility in 
Peirce's division, "It is easy to slip into referring to Peirce's three forms as 'types of signs,' but they are not necessarily mutually exclusive: a sign can be an icon, a symbol and an index, or any combination" (Signs section, para. 33) and as he continues "Signs cannot be classified in terms of the three modes without reference to the purposes of their users within particular contexts" (para. 33). To clarify this claim, Chandler illustrates the types of signs used in movies and TV programs:

Film and television use all three forms: icon (sound and image), symbol (speech and writing), and index (as the effect of what is filmed); at first sight iconic signs seem the dominant form, but some filmic signs are fairly arbitrary, such as 'dissolves' which signify that a scene from someone's memory is to follow (para. 33).

Keir Elam (2002) as a theatre semiotician hints to the historical process of semiotics from twentieth century on, "... [there are] two periods of intense and wide-based activity: the thirties and forties (with the work of the Czech formalists) and the past two decades (especially in France, Italy, Germany, the Soviet Union and the United States)." Semiotics has penetrated into literature, too, "the fortunes of the semiotic enterprise in recent years have been especially high in the field of literary studies, above all with regard to poetry and the narrative." Yet as Elam mentions "theatre and drama; meanwhile, have received considerably less attention, despite the peculiar richness of theatrical communication as a potential area of semiotic investigation" (p. 2).

\section{The Semiotics of Theatre and Drama}

As mentioned before, in spite of two decades of productive activity in the field of literary studies and literary genres such as poetry and narrative, drama has not received as much attention in semiotic studies as the two other genres. Indeed, such negligence in the semiotic study of drama seems incompatible with the potentiality and richness exists in semiotics dealing with signs and their meaning bearing behavior. Aston and Savona (2005), too, point to the thirties and forties as the period when Prague school "practitioners ... applied a semiotic methodology to artistic activity of all kinds" (p. 8). 
As Aston and Savona in Theatre as Sign-System mention, "fundamentally, we view theatre semiotics not as a theatrical position, but as a methodology: a way of working of approaching theatre in order to open up new practices and possibilities of 'seeing' “ (p. 1).

Semiotics is an approach wherein howness is dominant, so how meaning is created through signs is its first concern and as Aston and Savona refer to it, "the semiotic enquiry into how meaning is created and communicated through systems of encoded and decoded signs, have changed the nature and function of literary criticism" (p. 3). Indeed, this change has caused the emergence of "new way of interrogating the text and the generation of a methodology or 'language' with which to tackle the complexity of the theatrical sign system" (p. 3).

Before proceeding any further in surveying the semiotics of drama, since this paper has been written based on "Dramatic text" of Tennessee Williams' Camino Real and its "performance text" was not available, it seems crucial to differentiate between what Keir Elam (2002) refers to as "performance text" and "dramatic text" (p. 3); Differentiating the "performance text" from "dramatic text," Elam states:

Unlike the literary semiotician or the analyst of myth or the plastic arts, the researcher in theatre and drama is faced with two quite dissimilar - although intimately correlated — types of textual material: that produced in the theatre and that composed for the theatre. These two potential focuses of semiotic attention will be indicated as the theatrical or performance text and the written or dramatic text respectively (p. 3).

In "dramatic texts" as a paper work the only source that besides characters' interlocutor helps in grasping the meaning of play is stage directions. In Williams' plays stage direction in dramatic texts includes his meticulous description of the use of such stage props as light, music, symbolic objects, time fluctuation, colors, even stage decoration and other examples that we will see in Camino Real.

\section{Stage Directions}

It seems that throughout the history of theatre and drama, stage directions have not been considered very seriously and as Veltrusky 
explains some critics assume stage directions, "as something external to the play, something that does not really belong to its literary structure" (as cited in Aston and Savona, 2005, 71). For common readers and those who are not expert, stage direction means nothing, since they assume the text of the play as a narrative text wherein events and story are important; therefore, they pass the stage descriptions hastily to get to the dialogue lines.

Ingarden, as mentioned in Aston and Savona, "employs the terms Haupttext (primary text) and Nebentext (ancillary text) to differentiate between the dialogue of the character and the stage directions which frame that dialogue" (p. 72). As mentioned, in a dramatic text the stage direction is distinct from the characters' dialogue, through italicization or paranthecization (p. 72). The distinction between these two kinds of dialogue proves the significance of stage props in a dramatic text since besides the characters' direct utterance it conveys certain type of information to the reader and talks for itself.

Ingarden's distinction of Haupttext from Nebentext and the significance he ascribed to haupttext was not welcomed by some critics like Esslin who according to Aston and Savona believed that, "of the printed play-text, only the Hauptext is 'available to the spectators of a performance as a producer of meaning' "; in fact, he "asserts the primacy of the Nebentext over the Haupttext" (p. 73). But such critic as Veltrusky is in favor of Ingarden's classification and has espoused it. As Aston and Savona point to it, "Veltrusky takes the opposite position" to Esslin's claim; "he acknowledges that stage directions are integral to the ' literary structure' of the play and that they 'assume very important functions in its semantic construction' “ (p. 73). Some critics like Roman Ingarden, as Birch (1992) mentions, believes that, "stage directions, amongst other things like character's naming, textual and production histories, critical reception, mise-en-scene and so on, are as much part of the main text as the words assigned to the characters to speak and should not, therefore, be marginalized as 'side text' “ (p. 11). Disputes of such sort are interminable and futile since each group endeavors to stable its own position

Tennessee Williams is one of the dramatists who use notes or stage directions in his plays. In Veltrusky's term in the dramatic texts "meanings are conveyed by two entirely different forms of language- the speeches attributed to the interlocutors and the author's notes (usually called stage directions)" (as cited in Aston and Savona, 2005, p. 74). Stage directions play the same role for reader in dramatic text as the one performance on 
stage does for audience. It shows how stage props are used to produce and convey meaning. Cookson (1987) defines props in drama,

Props (which is short for 'properties') are the physical objects that characters may need to use in a drama in order to carry out certain actions and often both the items and the actions will be merely routine. But it is also possible in a play for props to come to stand for to suggest particular ideas or attitudes. As in such cases, the way in which characters regard or handle specific objects can assume considerable dramatic importance (p. 73).

In this manner, semiotically speaking, the appearance of each stage prop as a nonverbal element in drama may be a sign for a hidden meaning, but to which category of Pierceian taxonomy they may belong?

\section{Pierceian Taxonomy and Theatrical Signs}

To which group of signs the theatrical sign does belong? According to the aforementioned descriptions each sign might belong to one class of Peirceian sign's taxonomy: iconic, indexic or symbolic. But according to Peirce no sign can be classified exactly and specifically as icon, index or symbol. The same is true for the theatrical signs, whereas according to Aston and Savona, "some of the earlier semiotic studies of theatre posited theatre as an iconic activity, or actor as icon. However, subsequent analysis has pointed towards the difficulties of attempting to adhere rigidly to these categories when it is clear that theatrical signs are characterized by overlap and complexity" (Aston and Savona, 2005, p. 6). Assuming theatre as a compound art composing of various ranges of other arts, the difficulty of such classification becomes clear.

As Clay and Krempel (1967) state, "the essential meaning of play is expressed through the impact of its form" (p. 27). Considering the dramatic form as a system of signs, all its compounding elements, lighting, music, color, costumes, stage props, etc. become sign. "Czech theoreticians established the premise that everything in the theatrical frame is a sign" (p. 8), and Honzle (as cited in Aston and Savona, 2005) believes that "dramatic performance is a set of signs" (p. 8). Artaud (1958) maintains that theatre, "makes use of everything- gestures, sounds, words, screams, 
lights, darkness," and in this way "rediscovers itself at precisely the point where the mind requires a language to express its manifestation" (p. 12).

Talking about the role of signs on stage, different theoreticians posed their theories. Some of them believe that, as mentioned before, an actor's or an object's presence on stage is enough to turn it into a sign and when objects appear on stage their ordinary and usual role and application are suppressed in favor of their meaning on stage, that is why stage transforms objects into signs and their significance is determined based on their stage role.

\section{CAMINO REAL}

Tennessee Williams wrote one of his most imaginative plays, Camino Real in 1953. One of the repetitious themes of this play is the fractured dreams and the fear of future, coming to terms with the thought of growing older. The key to realize Williams' plays is that Camino Real is but another variation on Williams' signature theme: the heroic, doomed and inescapable struggle of romantic sensibilities too fragile to withstand the brutal out slaught of the modern life. Only here, instead of telling the victim's story from the outside, the perspective is turned inward. The young American visitor, Kilroy, in the play fulfills the role of a narrator. Gutman is another important figure of the play that has a hotel whose terrace occupies part of the stage. Another characteristic which distinguishes this play is the large cast of characters from Don Quixote and his partner Sancho to Lord Byron and many other literary figures.

The paralysis of settlers, the different sorts of contradiction that result in their alienation and their indifference toward each other, the caged birds and the lack of freedom even after death, etc. all are implied through stage props and signs which will be discussed based on Piercein taxonomy.

\section{The Objectification and Semiotization of Contradiction and Alienation through Stage Props}

Asserting the significance of contradiction in the play Cless (1983) mentions,

The contradictory world the play depicts and the episodic plot Williams uses to depict that world define Camino Real as a structure 
alienated in itself. Moreover, in its thematic structure the play is about characters who are alienated from themselves, from each other, and from their society or culture (p. 41).

Contradiction to what Cless asserts in Camino Real begins from the very point the play is created. It appears both in the thematic and the physical structure of the play, since both the inside and outside of this artistic world needs to be espoused mutually. This play is an episodic structure of sixteen dreamlike blocks. We can consider this structure as an iconic sign, the very picture of the way Camino Real settlers live. Yet it might be symbolic too, since the separation between each episode is reverberated in characters' life. Therefore alienation is symbolically implied from the very beginning by the way play is organized.

Thematically speaking, contradiction appears in the life of such characters as Kilroy, "a legendry American 'fighter' (both boxer and soldier)" (Cless, 1983, p. 43), who like other characters is trapped in his role dualism and it is the same for other characters, "For instance, Kilroy is champ/clown and Casanova is con-man/cuckold" (p. 44). Kilroy is a boxing champion, a Yankee caught in Camino Real and unable to escape. The more he tries to resist, the more he is oppressed and belittled by a supreme power like Gutman. He is not only a paralyzed trapped traveler in Camino Real who is robbed by anonymous starving settlers, but also an overwhelmed person who is losing his true identity. Gutman forces him to put patsy clothes on. He refuses to comply, but Gutman's guards chase him and at last Kilroy is a patsy!

Gutman: Here boy! Take these.

Kilroy: what is this outfit?

Gutman: The uniform of patsy.

Kilroy: I know what a Patsy is- he is clown...but I'm no patsy!

Gutman: pick it up.

Kilroy: Don't give me orders. Kilroy is a free agent-

Gutman [smoothly]: But a patsy isn't...you are now a patsy (Williams, 1958, p. 159).

Kilroy's resistance against Gutman guards is futile. At the end of Block six, he is a patsy to amuse Gutman! 
Gutman: Hush! The patsy doesn't talk. He lights his nose, that's all! Guard: Press the little botton at the end of the cord.

Gutman: That's right. Just press the little botton at the end of the cord! [Kilroy lights his nose. Everybody laughs] (p. 163).

This alienation and the loss of identity is the direct result of Gutman's controlling forces. He is the God-like figure who announces the end of each part and the beginning of a new Block. He leads the play in sixteen Blocks. In this play alienation does not mean only personal alienation and person's estrangement from him/herself, but it appears in a larger and wider scale, what Cless (1983) calls "societal alienation" (p. 49).

In the prologue of his play, Williams describes the geographical location of Camino Real in such a way in which the town is divided into two different classes of people. This class contradiction, thematically and physically, is another way of delineating social alienation. People in Camino Real are classified and labeled based on the way Gutman and others treat them.

On the stage left is the luxury side of the street, containing the facade of the Siete Mares Hotel and its low terrace on which are number of glass-topped white iron tables and chairs"..."opposite the hotel is Skid Row which contains the Gipsy's gaudy stall, the loan shark's establishment with a window containing a variety of pawned articles, and the 'Ritz Men Only' which is a fleabag hotel or flophouse... (Williams, 1958, p. 125).

Camino Real is a society wherein people are forced to be strange and indifferent toward each other. Gutman is the all controlling eye of the town who orders his agents to watch people and their treatment. As Cless (1983) maintains:

]In comments related to a 1970 revival, Williams stated his belief that Camino Real is primarily about 'a fascist state and the dilemma of the individual caught in it. On a larger scale, the play is about modern social alienation resulting from oppression or repression by social institutions and political systems which seem beyond the grasp of the people caught inside them (p. 50). 
Under the controlling eyes of Gutman and his agents, Camino Real is like an isolated Island completely blocked for those who wish to escape from its inevitable control. Those who enter it are trapped and devoid of freedom and liberty. They have to be what Gutman wishes, like Kilroy who becomes a patsy. In geographical description of Camino Real, Williams depicts an extended desert:

Upstage is a great flight of stairs that mount the ancient wall to a sort of archway that leads out into 'Terra Incognita', as it is called in play, a wasteland between the walled town and the distant perimeter of snow-topped mountains. Downstage right and left are pair of arches which give entrance to dead-endstreet (Williams, 1958, p. 125).

It seems that Camino Real is nowhere; it is blocked by an expanded and unknown wasteland from which no one has been able to pass; it is the very appearance of death. Semioticly considering by depicting Camino Real in such dead-end Williams puts emphasis on modern man's alienation and entrapment. Till now the dual identity of characters, the geographical location of Camino Real in a wasteland leading nowhere, the class distinction of people and their paralysis were staged by different signs. The flexibility of signs let us to range them as iconic, indexical or symbolic. Camino Real is surrounded by desert therefore settlers are forced to stay there. In this way Camino Real's location might be indexical sign of some phenomenological relation between peoples' fears and the frustration of their hopes and their mandatory existence in that inferno.

Lord Byron is one of the legendry characters of the play who is determined to leave Camino Real to face the unknown wasteland:

Gutman: You are leaving us Lord Byron?

Byron: yes, I am leaving.

Gutman: what a pity! But this is a port of entry and departure. There are no permanent guests...

$\cdots$

Byron: make a departure.

Gutman: From yourself?

Byron: from my present self to Myself as I used to be!

Gutman: That's the farthest departure a man could make! ... 
Gutman: Struggle for what?

Byron: for freedom! You may laugh at it, but it still means something to me! (p. 176)

Continuing his conversation with Gutman, Byron says, "There is a time for departure even when there is no certain place to go" (p. 180). When Lord Byron heads toward the desert the music begins, intensifying the feeling of departure. Byron's leading toward the wasteland startles other settlers of Camino Real. That is why Marguerite asks Jacques to warn Lord Byron against moving that way. Marguerite, "Jacque, run after him, warn him, tell him about the desert he has to cross" (p. 180).

While music is still playing and accompanying Byron's departure "the desert wind sings loudly as Byron climbs to the top of the steps" (p. 181). The sound of music and desert winds are like external reverberations of what passes through the heart and mind of other characters, seeing Lord Byron's leaving the sanctuary! It concretizes their horror and palpitation; it is iconic sign of some abstract feeling. Not only iconic but it is the symbol of some unknown adventure and the fear accompanies it.

At their arrival to Camino Real, Sancho reads the map loudly for Don Quixote; "And naw. I know this place... here it is on the chart. Look, it says here: 'continue until you come to the square of a walled town which is the end of Camino Real and the beginning of the Camino Real" (p. 128). As Cless (1983) points to it Camino Real means "the royal way" and Camino Real means "the real way" (p. 43). From the very title of the play one may recognize its strange structure, something peculiar to the world Williams has created, using all elements, from the stage props to the name of the characters and their dialogue.

In creating his new world, Williams uses different elements to make the play concise but communicative to the reader,

I can't deny that I use a lot of those things called symbols but being a self-defensive creature, I say that symbols are nothing but the natural speech of drama. We all have in our conscious and unconscious minds a great vocabulary of images, and I think all human communication is based on these images as are our dreams; and a symbol in a play has only one legitimate purpose which is to say thing more directly and simply and beautifully than it could be said in words (Williams, 1958, p. 121). 


\section{Caged Birds as the Semiotization of Entrapment}

Williams is an expressionist who prefers the frugal use of stage props to express what passes through his mind. He likes to express long lines of words in a moment of light or music. He prefers to use bird cage as a part of stage to force the reader to see and to sense the concept of prison directly. At the very beginning of this play, he describes the feeble rays of dawn as a white bird "caught in a net and struggling to rise" (p. 125).

Not only the geographical isolation of Camino Real but also several references to the caged birds intensify the sense of entrapment and alienation of people in this play. In this sense caged bird is the iconic sign for the sense of entrapment and isolation.

In Block 7 during a conversation between Marguerite and Jacques, Marguerite wishes to leave Camino Real and Jacques encourages her to stay, but she points to the caged birds' desire for freedom and fly, "Caged birds accept each other but flight is what they long for" (p. 173). She compares themselves to caged birds that are forced to live in a cage and accept its limitations while in the depth of their heart freedom is what they really desire. Jacques has accepted the cage when he says, "there are no flights out of here till further orders from someone hire up" (p. 173).

Again the idea of caged birds and the lack of freedom are repeated in the last scene when Lord Byron is moving toward the wasteland, "to several porters carrying the luggage which is mainly caged birds..." (p. 181). When Don Quixote and his companion Sancho arrive at the gate of Camino Real, the caged bird is a point of reference in their conversation: "Quixote [he snatches the chart from him and reads the rest of the inscription]: '__ there are no birds in this country except wild birds that are tamed and kept...in cages!” (p. 128)

\section{Lighting and its Semiotic Implication}

To inculcate the sense of loneliness in readers' mind, Williams plays with light as another device to back up the feeling that sound of desert wind and music create in play. "I feel, as the painter did, that the message lies in those abstract beauties of form and color and line, to which I would add light and motion" (p. 122). In the prologue of Camino Real Williams describes the stage where there is no light. Here the scene is like a white sheet on which no word has been written by ink. Light alongside the music 
are used to help the verbal language to articulate the message which language by itself is not eloquent enough to express fruitfully. "As the curtain rises, on an almost lightless stage, there is a loud singing of wind...the flickers of a white radiance as though day break were a white bird caught in a net and struggling to rise" (p. 125).

The action of play starts with the appearance of "a shaft of blue light" when Don Quixote and Sancho enter the stage: "Immediately after the curtain rises a shaft of blue light is thrown down a central aisle of theatre, and in this light, advancing from back of the house appears Don Quixote de la Mancha" (p. 126).

Quixote and Sancho's dialogue revolves around the significance of the blue color and its meaning for noble men:

Quixote [Ranting above the wind in a voice which is nearly as old]: Blue is the color of distance!

Sancho [wearily behind him]: Yes, distance is blue.

Quixote: Blue is the color of distance and nobility, and that is why an old knight should always have somewhere about him a bit of blue ribbon...

[He jostles the elbow of an aisle-sitter as he staggers with fatigue; he mumbles an apology.]

Sancho: Yes, a bit of blue ribbon.

Quixote: a bit of faded blue ribbon...It serves to remind an old knight of distance that he has gone and distance he has yet to go..." (p. 126).

During the play whenever blue light appears, it announces the entrance of a legendry character. As it was with Don Quixote's entrance, the appearance of Camille or Lady Marguerite is accompanied with blue light:

A Hunchback Mummer Somersaults through his hoop of silver bells springs up and shakes it excitedly toward a downstage arch which begins to flicker with a diamond-blue radiance; this marks the advent of each legendry character in the play. The music follows: a Waltz from the time of Camille in Paris (p. 166).

At this point light and music are simultaneous. The music of waltz is the reminiscence of the glorious days of Camille in Paris. This short music 
appears like a sparkle and disappears very soon as if tried to tell us those days are gone and now Camille is forced to face a new world in Camino Real where each person is ensconced in his/her own world and memories. Therefore music here is the symbolic sign of time fluctuation and the short juxtaposition of past and present, yet it can be the indexical sign of Camille's memories, a reflection of her inner thoughts; because she recalls her past in comparison with today, she feels the music of past glory.

\section{The Significance of Legendry Characters}

Dealing with such large cast of legendry characters in one place seems strange. As Cless (1983) states, 'In Williams' word they are 'mostly archetypes of certain basic attitudes and qualities...they seem strange, perhaps distant, lacking the heartfelt sympathy or identification invoked by most characters in other plays by Williams" (p. 45).

As Williams mentions, these characters are "strange and distant" and this direct clue in choosing such characters justifies the use of blue light whenever one of them steps on stage. Blue light is an inseparable part of their world which is concretized on stage to deepen their sense of seclusion and estrangement; consequently, it can be both iconic, an equivalent of this seclusion and its projection, and also symbolic in which the relation of signifier (the blue light) and the signified (seclusion and isolation) is learned gradually by the reader through other evidences in play.

Camino Real is microcosm of modern macrocosm wherein modernization and ruling laws have made people choose an Ivory Tower for themselves. What Williams tries to delineate through these legendry characters and the way stage props support them when they come to focus, is a sort of generalization. He wishes to show macrocosm in a microcosm, and to depict the modern man's loneliness through the figures that are familiar and this familiarity prepares the reader to experience it. So, one might assume the whole play as an iconic sign which is the verisimilitude of universe in one stage and its characters.

"In short to be in Camino Real is to be locked into an existential holding pattern. The characters are trapped the contradiction in a place where genuine escape or change is seemingly impossible" (p. 44). These characters are not individuals, they are types to debase this thought in the reader's mind that they are separated from this dreamlike world, since this is the very world in which they are living unconsciously. Cless points to 
Williams' idea about Camino Real and its characters, "this fantasy... concerns the world's dispossessed, the victims of circumstances, the rootless. The hero is a folk character, Kilroy, who here is a sort of Everyman" (p. 44).

People in Camino Real are incapable of any change, since they are under the controlling eyes of Gutman and his agents. In this town the "forbidden word" of "Hermano", which means brother, (Williams, 1958, p. 139) should never be pronounced since it leads toward social agitation and the breakdown of Gutman's government.

The first time in the play that the terror of the forbidden word is expressed by Gutman is when a stranger referred to as the Survivor, looking for water heads toward the dried fountain of the square. Unable to find water in the dried fountain and sure about the existence of water in Sietes Mares the Survivor moves toward the hotel. Seeing the Survivor's determination, the guards put on fire at him and he dies gradually and pathetically near the dried fountain. This is the same fountain Don Quixote and Sancho at their arrival point to it, "turn back, Traveller, for the spring of humanity has gone dry in this place..." (p. 128) Regarding the importance of this dried fountain in the center of Camino Real's plaza Cless (1983) declares, "The dried fountain in the center of the plaza symbolizes a universal loss of community and tradition in the wake of modern exploitation with its accompanying materialism and decadence" (p. 50). As Cless vividly explains, this fountain is a symbolic sign.

Hermano is the forbidden word in Camino Real, meaning brother! As mentioned before, people of this society are forced to be separated and indifferent toward each other. They are inevitably forced to bear seclusion and isolation. Their mouth is shut by the ruling power of the town that is why Camino Real's location is described as an isolated Island, since people are forced to be there and accept it. In a conversation between Kilroy and Jacques in Block five, Jacques describes how people even after death are not free and their body is a part of states' properties:

Jacques [smiling into sunset glow]: "the exchange of serious questions and ideas, especially between persons from opposite sides of the plaza, is regarded unfavorably here... Now you want to know what is done to a body from which the soul has departed on the Camino Real!_ Its disposition depends on what the street cleaners happen to find in its pockets. If its pockets are empty as the 
unfortunate Baron's turned out to be, and as mine are at this moment_the 'stiff' is wheeled straight off to the laboratory. And there the individual becomes an undistinguished member of a collectivist state. His chemical components are separated and poured into vats containing the corresponding elements of countless others. If any of this vital organs or parts are at all unique in size or structure, they're placed in bottles containing a very foul-smelling solution called formaldehyde. There is a charge of admission to this museum. The proceeds go to the maintenance of the military police (Williams, 1958, p. 155).

Cless (1983) believes that, "Gutman and his thugs exercise a ruthless control over the Camino in the same way as various modern authoritarian regimes" (p. 50).

\section{CONCLUSION}

Although semiotics has an expanded area appearing almost in all human affairs including poetry and narratives, drama received its attention lately. Charles Sanders Pierce defined different taxonomies for signs and their significance from which icon, index and symbol have been used in this paper. Following Pierce, theatre experts used signs defining meanings produced in drama by both dramatic and performance texts. Tennessee Williams as an important figure in American Drama wrote many plays in which Dramatic texts are as vivid as the performance ones. Camino Real, his imaginative and surrealistic play is one of his works which is full of such stage props as light, music, time fluctuation, symbolic objects, colors, archetypal characters, caged birds, etc. which can be assumed as semiotization of untouchable concepts. They might be icon, symbol and index or a combination of all of them.

\section{REFERENCES}

Artaud, A. (1958). The theatre and its double. (M.C. Richards, Trans.). New York: Grove Press.

Aston, E., \& Savona, G. (2005). Theatre as sign-system: A semiotics of text and performance. New York: Routledge. 
Birch, D. (1992). The language of drama: Critical theory and practice. Hong Kong: Macmillan.

Chandler, D. (1994). Semiotics for beginners. Retrieved December 2010, from http://www.aber.ac.uk/media/Documents/S4B/semiotic.html.

Cookson, L. (1987). Practical approach to literary criticism. (R. Adams, Ed.). London: Longman.

Clay, J. H., \& Krempel, D. (1967). The theatrical image. New York: McGraw-Hill.

Cless, D. (1983). Alienation and contradiction in Camino Real: A convergence of Williams and Brecht Author(s). Theatre Journal, 35(1), 41-50.

Durham, F. (1971). "Tennessee Williams, Theatre Poet in Prose." South Atlantic Bulletin. Vol. 36, No. 2, pp. 3-16.

Elam, K. (2002). The Semiotics of Theatre and Drama. $2^{\text {nd }}$ ed. New York: Routledge.

Fleche, A. (2010). "The space of madness and desire: Tennessee Williams and Streetcar." Modern Drama. Vol. 38, No. 4, P. 496. Academic Research Library, ProQuest. Web. 2 Jan.

Jackson, E.M. (1975). "Tennessee Williams." The American Theatre. Ed. Allan S. Downer. Washington, D.C.: Voice of America Forum Series. Pp. 81-95.

Scholes, R. (1982). Semiotics and interpretation. London: Yale University Press.

Newton, K. M. (Ed.). (1990). Twentieth-century literary theory. London: Macmillan.

Williams, T. (1958). Camino real. (E. M. Brown, Ed.). Aylesbury: Penguin. 